\title{
Parasitism by Monogenoidea in Piaractus mesopotamicus (Characiformes, Characidae) cultivated in Paraná River (Brazil)
}

\author{
M. S. L. Leão ${ }^{a *}$, M. C. N. Justo ${ }^{b}$, G. W. Bueno ${ }^{c}$, S. C. Cohen ${ }^{b}$ and S. C. São Clemente ${ }^{d}$ \\ aPrograma de Pós-graduação em Higiene Veterinária e Processamento Tecnológico de Produtos de Origem Animal, \\ Laboratório de Inspeção e Tecnologia de Pescado, Faculdade de Veterinária, Universidade Federal Fluminense - UFF, \\ Rua Vital Brasil, 64, Santa Rosa, CEP 24320-340, Niterói, RJ, Brazil \\ ${ }^{\text {b} L a b o r a t o ́ r i o ~ d e ~ H e l m i n t o s ~ P a r a s i t o s ~ d e ~ P e i x e s, ~ I n s t i t u t o ~ O s w a l d o ~ C r u z ~-~ F I O C R U Z, ~ A v e n i d a ~ B r a s i l, ~ 4365, ~}$ \\ CEP 21045-900, Rio de Janeiro, RJ, Brazil \\ ${ }^{\mathrm{c}}$ Faculdade de Engenharia de Pesca, Universidade Estadual Paulista - UNESP, Avenida Nelson Brihi Badur, 430, \\ CEP 11900-000, Registro, SP, Brazil \\ ${ }^{d}$ Laboratório de Inspeção e Tecnologia de Pescado, Faculdade de Veterinária, Universidade Federal Fluminense - UFF, \\ Rua Vital Brasil, 64, Santa Rosa, CEP 24320-340, Niterói, RJ, Brazil \\ *e-mail: mari.lopess@ioc.fiocruz.br
}

Received: January 11, 2016 - Accepted: July 19, 2016 - Distributed: November 31, 2017

\begin{abstract}
This study investigated the occurrence, prevalence, mean abundance and mean intensity of monogenoidean parasites in Piaractus mesopotamicus farmed in cages in the reservoir of the Itaipu Hydroelectric Power Station, Paraná River, Brazil. The parasite distribution pattern and the correlation of prevalence and abundance with the total length of hosts were also investigated. Four monogenoidean species were collected: Anacanthorus penilabiatus, A. toledoensis, Mymarothecium ianwhitingtoni and M. viatorum. All the parasites collected in P. mesopotamicus showed the typical aggregated distribution pattern, and the abundance and the prevalence did not shown any correlation with the total length of hosts.
\end{abstract}

Keywords: Monogenoidea, Piaractus mesopotamicus, Paraná River, Anacanthorus, Mymarothecium.

\section{Parasitismo por Monogenoidea em Piaractus mesopotamicus (Characiformes, Characidae) cultivados no rio Paraná (Brasil)}

\section{Resumo}

Neste estudo foi investigada a ocorrência, prevalência, abundância média e intensidade média de Monogenoidea parasitos de Piaractus mesopotamicus, cultivados em tanques-rede no reservatório da Usina Hidrelétrica de Itaipu, rio Paraná, Brasil. Foram investigados ainda o padrão de distribuição parasitária e a correlação entre a prevalência e abundância com o comprimento total dos hospedeiros. Quatro espécies de Monogenoidea foram coletadas: Anacanthorus penilabiatus, A. toledoensis, Mymarothecium ianwhitingtoni e M. viatorum. Todos os parasitos coletados em P. mesopotamicus apresentaram típico padrão de distribuição agregada e não foi observada correlação entre a abundância e a prevalência e o comprimento total dos hospedeiros.

Palavras-chave: Monogenoidea, Piaractus mesopotamicus, rio Paraná, Anacanthorus, Mymarothecium.

\section{Introduction}

Piaractus mesopotamicus (Holmberg, 1887) is a characiform fish commonly known as "pacu" in Brazil. This fish reaches maturity at a length of $40.5 \mathrm{~cm}$ and is one of the most commonly farmed species in Brazil, because of its importance for the food diet, ecology and sport fishery (Jégu, 2003). The significant increment in aquaculture around the world has increased the importance of studies of parasites and other pathogens of aquatic organisms, especially in those hosts that have the potential for production and sale (Luque, 2004). The monitoring of parasites and other fish pathogens is an important part of prophylactic management both for production (Pavanelli et al., 2008). Parasitic infections are more relevant in the Neotropical region because of the climatic characteristics of this region, which facilitate the rapid and continuous spread of these pathogens (Thatcher and Brites-Neto, 1994). The Monogenoidea are one of the largest groups of parasitic flatworms, comprising about 60 families and more than 3000 described species. Some species have detrimental effects on both wild and farmed fish populations, causing 
important economic damage (Fannes et al. 2015). Several authors have studied monogenoideans in P. mesopotamicus: to date, parasitological (Alexandrino et al., 1995; Eiras et al., 1995; Kohn and Cohen, 1998; Martins et al., 2002a; Pamplona-Basilio et al., 2001; Schalch et al., 2006; Lizama et al., 2007; Cohen and Kohn, 2005, 2009; Franceschini et al., 2013), histopathological (Martins and Romero, 1996; Campos et al., 2011; Tavares-Dias et al., 2002; Jerônimo et al., 2014), morphological (Boeger et al., 1995; Souza et al., 2000; Cohen and Kohn, 2008; Leão et al., 2015), pathological (Tavares-Dias et al., 2000), hemathological (Martins et al., 1995; Tavares-Dias et al., 2002, 2008) and terapeutic (Martins, 1998; Martins et al., 2000, 2002b; Tavares-Dias et al., 2002; Onaka et al., 2003; Belo et al., 2005; Schalch et al., 2006; Cruz et al., 2008; Fujimoto et al., 2010; Figueiredo et al., 2011; Carraschi et al., 2014) studies were conducted. The first monogenoidean found in "pacus" was Anacanthorus penilabiatus Boeger, Husack and Martins, 1995, described in the state of São Paulo and posteriorly reported by Martins et al. (2000) in the same region. One year later, Pamplona-Basilio et al. (2001) presented the descriptions of the egg and reported this species in another host, Colossoma macropomum (Cuvier, 1818). Mymarothecium viatorum Boeger, Piasecki and Sobecka, 2002 was originally described from Piaractus brachypomus (Cuvier, 1818) in Poland and later, it was reported by Cohen and Kohn (2005) parasitizing P. mesopotamicus in the state of Ceará, Brazil. Franceschini et al. (2013) reported findings of $A$. penilabiatus and $M$. viatorum in the same host. In 2007, Lizama et al. recorded A. penilabiatus, Anacanthorus spatulathus and Mymarothecium sp. from the same host. Recently, Leão et al. (2015) described two new species, Anacanthorus toledoensis and Mymarothecium ianwhitingtoni, increasing the diversity of known species of Monogenoidea in P. mesopotamicus. The aim of the present study was to investigate prevalence, mean abundance, mean intensity, parasite distribution pattern and the correlation of prevalence and abundance with the total length of hosts of monogenoidean parasites in P. mesopotamicus farmed in cages in the reservoir of the Itaipu Hydroelectric Power Station, Paraná, Brazil.

\section{Material and Methods}

In january 2011 (summer season), samples of gills were taken from forty-one $P$. mesopotamicus that were kept in cages upstream and downstream of the reservoir of the Itaipu Hydroelectric Power Station, Paraná River, state of Paraná, Brazil (2444'29.0” S; 5344'51.2” W).
During all the cultive period water physical and chemical parameters were measured with portable devices. Dissolved oxygen (Hanna Instruments, model HI9146) and pH (Hanna Instruments, model HI8314) were weekly monitored as the water temperature was monitored daily (mornings and evenings) with a mercury bulb thermometer. The fish were anesthetized with benzocaine at a concentration of $74 \mathrm{mg} / \mathrm{L}$ and euthanized with benzocaine at a concentration of $250 \mathrm{mg} / \mathrm{L}$ according to the recommendations of Gomes et al. (2001), weighed (g), measured (cm) and transported to the laboratory. The gills were removed and placed in vials containing 1:4000 formalin solution and shaken vigorously and the formalin solution of each vial was increased to about 5\%. In the laboratory, parasites were collected with the aid of a stereoscopic microscope and were stored in the same fixative. Some specimens were mounted unstained in Hoyer's mounting medium (Humason, 1979) in order to study the sclerotized parts and the remaining were stained with Gomori's trichrome, cleared in beechwood creosote and mounted on slides in Canada balsam (Kritsky et al., 1978).

The prevalence (P), mean abundance (MA) and mean intensity (MI) of the parasites were calculated as described by Bush et al. (1997).

The index of dispersion (quotient between variance and mean of parasite abundance) and d test were used to determine distribution patterns (Ludwing and Reynolds, 1988). Spearman's rank correlation coefficient ( $r s)$ was used to determine possible correlations between host'stotal length and parasite abundance. Pearson's correlation coefficient $(r)$ was used to determine possible correlations between the host's total length and the prevalence of parasites, with angular transformation of prevalence values (Zar, 1996). The statistical significance level of $\mathrm{p} \leq 0.05$ was used.

\section{Results and Discussion}

The average values for the physical and chemical water parameters measured during the experimental period were $30.4 \pm 0.7^{\circ} \mathrm{C}$ for temperature; $6.40 \pm 0.3 \mathrm{mg} / \mathrm{L}$ for dissolved oxygen; $7.1 \pm 0.3$ for $\mathrm{pH}$; and $0.06 \pm 0.03 \mathrm{mg} / \mathrm{L}$ for ammonia content (as shown in Table 1). These values are within the recommended range when rearing tropical species (Ostrensky and Boeger, 1998; Urbinati et al., 2010). Features of the habitat (local abiotic factors such as water temperature, $\mathrm{pH}$ and lakesize) and certain traits of the host population like size, could facilitate the transmission and establishment of fish parasites (Bagge et al., 2004; Takemoto et al., 2005; Poulin, 2006).

Table 1. Values for the physical and chemical water parameters measured during the experimental period.

\begin{tabular}{ccc}
\hline Parameters & Values & References values \\
\hline Temperature $\left({ }^{\circ} \mathrm{C}\right)$ & $30.4 \pm 0.7$ & $20-30^{*}$ \\
Oxygen dissolved & $6.40 \pm 0.3 \mathrm{mg} / \mathrm{L}$ & $3-10^{\dagger}$ \\
$\mathrm{pH}$ & $7.1 \pm 0.3$ & $6-8^{* \dagger}$ \\
Ammonia content & $0.06 \pm 0.03 \mathrm{mg} / \mathrm{L}$ & $<0.6^{*}$ \\
\hline
\end{tabular}

*Ostrensky and Boeger (1998); 'Urbinati et al. (2010). 
Forty-one specimens of $P$. mesopotamicus with mean total weight $1.13 \mathrm{Kg}(0.690-1.726 \pm 0.264 \mathrm{Kg})$ and mean total length $35.07 \mathrm{~cm}(30-41 \pm 2.493 \mathrm{~cm})$ were examined for monogenoideans. All the fish examined were parasitized with at least one species of Monogenoidea. Four species were collected: Anacanthorus penilabiatus, Anacanthorus toledoensis, Mymarothecium ianwhitingtoni and Mymarothecium viatorum (as shown in Table 2). A. toledoensis was the species with higher rates of prevalence, mean intensity and mean abundance. The other three species have high rates of prevalence, but low values of mean intensity and mean abundance: A. penilabiatus; M. viatorum; $M$. ianwhittingtoni.

Our results, compared with other studies, showed variations in the mean abundance and mean intensity of monogenoidean (as shown in Table 3). Lizama et al. (2007), Tavares-Dias et al. (2008), Franceschini et al. (2013) and Jerônimo et al. (2014) reported the prevalence indexes for A. penilabiatus in P. mesopotamicus in fish farming ( $\mathrm{P}=81.1 \% ; 76 \% ; 77.3 \% ; 100 \%$, respectively) that were similar to what was reported in this study ( $P=97.5 \%)$, but higher from the studies of Martins and Romero (1996) and Cohen and Kohn (2009) ( $\mathrm{P}=33.3 \%$; $50 \%$, respectively). Considering mean intensity and mean abundance, Franceschini et al. (2013) (MI = 22.4; $\mathrm{MA}=17.3)$ and Cohen and Kohn (2009) $(\mathrm{MI}=23.6$; $\mathrm{MA}=11.8)$ demonstrated similar results for A. penilabiatus, while other studies register higher values: (Lizama et al. (2007) $\mathrm{MI}=166,3 / \mathrm{MA}=134,9$; Tavares-Dias et al. (2008) $\mathrm{MI}=2,287.6$ and Jerônimo et al. (2014) MI=316.3 (cold season); 2,742.3 (hot season); $\mathrm{MA}=316.3$ (cold season); 2,742.3 (hot season).

The monogenoidean species reported in this study was also present in closely related fish species (as shown in Table 4). A. penilabiatus was reported in P. brachypomus, in hybrids $P$. mesopotamicus x C. macropomum and in P. mesopotamicus x P. brachypomus (Cohen and Kohn, 2009; Tavares-Dias et al., 2008; Franceschini et al., 2003). In the studies of Franceschini et al. (2013) (P. mesopotamicus $\mathrm{x}$ P. brachypomus) and Tavares-Dias et al. (2008) (P. mesopotamicus x C. macropomum) studies, the prevalence of $A$. penilabiatus was lower than in the present study. However, the prevalence presented by Cohen and Kohn (2009) for P. brachypomus was similar with our results for $P$. mesopotamicus. Considering the mean intensity, the hybrid examined by Tavares-Dias et al. (2008) showed high values than in the present study, while Cohen and Kohn (2009) and Franceschini et al. (2013) found similar values in mean intensity and mean abundance in $P$. brachypomus and in the hybrid $P$. mesopotamicus $\mathrm{x}$ P. brachypomus, respectively.

In the present investigation, $M$. viatorum showed values of mean intensity and mean abundance similar to those found by Franceschini et al. (2013) (MI = 27.5;

Table 2. Prevalence (P\%), mean intensity (MI), mean abundance (MA) range (R), intensity (I) and confidence interval (CI) of monogenoideans parasites of farmed fish, P. mesopotamicus of the reservoir of the Itaipu Hydroelectric Power Station, Paraná River, state of Paraná, Brazil.

\begin{tabular}{lccll}
\hline \multicolumn{1}{c}{ Parasites } & \multicolumn{1}{c}{ P(\%) } & \multicolumn{1}{c}{ MI (CI) } & \multicolumn{1}{c}{ MA (CI) } & \multicolumn{1}{c}{ R } \\
\hline Anacanthorus penilabiatus & $97.5(86.8-9.9)$ & $11.5(8.1-16.3)$ & $11.5(7.9-16.2)$ & $1-58$ \\
Anacanthorus toledoensis & $100.0(91.6-1.0)$ & $43.1(35.3-55.8)$ & $43.1(34.5-55.8)$ & $1-175$ \\
Mymarothecium ianwhitingtoni & $80(64.3-90.9)$ & $12.9(8.5-23.0)$ & $10.3(6.5-18.5)$ & $1-94$ \\
Mymarothecium viatorum & $95(83.0-99.3)$ & $27.1(18.8-42.7)$ & $25.7(17.8-40.9)$ & $2-188$ \\
\hline
\end{tabular}

Table 3. Dispersion index (DI) and $d$ statistical of the monogenoideans parasites of farmed fish, P. mesopotamicus of the reservoir of the Itaipu Hydroelectric Power Station, Paraná River, state of Paraná, Brazil.

\begin{tabular}{lcc}
\hline \multicolumn{1}{c}{ Parasites } & DI & $\boldsymbol{d}$ \\
\hline Anacanthorus penilabiatus & 14.2 & $24.5^{*}$ \\
Anacanthorus toledoensis & 26.8 & $35.9^{*}$ \\
Mymarothecium ianwhitingtoni & 29.5 & $39.2^{*}$ \\
Mymarothecium viatorum & 46.1 & $51.2^{*}$ \\
\hline
\end{tabular}

*Significant values.

Table 4. Values of Spearman's rank correlation coefficient ( $r s)$ and Pearson's correlation coefficient $(r)$ obtained in relations between total length of hosts and abundance and prevalence of monogenoideans parasites of farmed fish, P. mesopotamicus of the reservoir of the Itaipu Hydroelectric Power Station, Paraná River, state of Paraná, Brazil.

\begin{tabular}{lcccc}
\hline \multicolumn{1}{c}{ Parasites } & $\boldsymbol{r s}$ & $\mathbf{P}$ & $\boldsymbol{r}$ & $\mathbf{P}$ \\
\hline Anacanthorus penilabiatus & -0.1444 & 0.3739 & -0.378 & 0.1003 \\
Anacanthorus toledoensis & -0.1215 & 0.4553 & 0.2586 & 0.2709 \\
Mymarothecium ianwhitingtoni & -0.1807 & 0.2645 & 0.4282 & 0.0595 \\
Mymarothecium viatorum & -0.2069 & 0.2000 & 0.085 & 0.7216 \\
\hline
\end{tabular}


MA = 19.9), and different from Cohen and Kohn (2009) $(\mathrm{MI} ; \mathrm{MA}=277)$ from P. mesopotamicus.

Regarding the parasitism by $M$. viatorum on closely related fish of P. mesopotamicus, Cohen and Kohn (2009) presented similar prevalence values for parasitism in the host P. brachypomus, however, in the study of Vásques (2014) in the same host, these values were lower. Considering mean intensity and mean abundance, the studies of Cohen and Kohn (2009) and Vásques (2014) showed higher values. The prevalence of $M$. viatorum in hybrid (P. mesopotamicus $\mathrm{X}$ P. brachypomus) presented by Franceschini et al., (2013) showed similarity, while the mean intensity and mean abundance values were considerably higher than those from the present study. These differences are due to changes in the management of farming systems and susceptibility to infection of cultured individuals. The high indexes in farming mainly occurs due the Monogenoidea have a direct life cycle and their transmission could be facilitated by proximity between hosts (Bagge et al., 2004). These parasites in man-made environments, like aquaria and fish farms, multiply readily, sometimes killing their hosts (Rubio-Godoy, 2007).

All the parasites of $P$. mesopotamicus showed the typical aggregated pattern of distribution (as shown in Table 5). Our results show that these parasites present the typical aggregated distribution pattern, in conformity with the most common pattern for metazoan parasite populations. Poulin (2013) pointed that firstly, heterogeneity among host individuals in terms of exposure to parasites, resulting from the uneven distribution of infective stages in space and time relative to hosts, can lead to parasite aggregation. Secondly, heterogeneity in numbers of parasites per host can result from either genetic or acquired variation in susceptibility to infection, arising from differences among hosts in behaviour or immune resistance. More knowledge about parasite and host biology is needed to improve the interpretation of these parasitological patterns, in an ecological framework incorporating pertinent environmental and biological information, as recommended by Marcogliese (2001).

There was no correlation between abundance and total length of the hosts, and between prevalence and total length of the hosts (as shown in Table 6).

According Luque et al. (2003), the size of the host is not always correlated with prevalence and abundance of parasites. As pointed by Poulin (2000), this pattern cannot be generalized, because in many host-parasite systems the correlation is positive, but weak and non-significant. In the present study, no correlation was observed between the abundance and prevalence of the parasites and the total length of the hosts. This lack of correlation may be related to the low amplitude of the host length classes observed among the specimens examined. In cages this fact could happen frequently because the standardization of fish sizes. Similar results were observed in Plagiocion squamosissimus by Tavernari et al. (2005), who reported that the non existence of correlation of the Monogenoidea number and their prevalence in relation to the size of the hosts might be due to uniformity of parasitism levels in relation to host length classes, along with the situation in which almost all the host samples were adult specimens.

Table 5. Comparison between the values of prevalence (P\%), mean intensity (MI), mean abundance (MA), range (R), total number (n) of monogenoideans parasites of different localities and quality water.

\begin{tabular}{|c|c|c|c|c|c|c|c|c|}
\hline Parasite & $\mathbf{P}(\%)$ & MI & MA & $\mathbf{R}$ & $\begin{array}{c}\text { Total } \\
\text { (n) }\end{array}$ & Locality & $\begin{array}{c}\text { Quality of } \\
\text { water }\end{array}$ & Reference \\
\hline \multirow{7}{*}{ 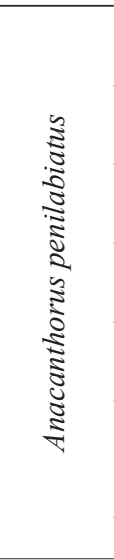 } & 33.3 & - & - & - & 37 & $\begin{array}{l}\text { São Paulo and } \\
\text { Paraná State }\end{array}$ & - & $\begin{array}{c}\text { Martins and } \\
\text { Romero (1996) }\end{array}$ \\
\hline & 81.1 & 166.3 & 134.9 & $2-2387$ & & São Paulo State & Unacceptable & $\begin{array}{l}\text { Lizama et al. } \\
(2007)\end{array}$ \\
\hline & 76 & $2,287.6$ & - & - & - & São Paulo State & Acceptable & $\begin{array}{c}\text { Tavares-Dias et al. } \\
\text { (2008) }\end{array}$ \\
\hline & 50 & 23.6 & 11.18 & $13-42$ & 74 & Ceará State & - & $\begin{array}{c}\text { Cohen and Kohn } \\
\text { (2009) }\end{array}$ \\
\hline & 77.3 & 22.4 & 17.3 & - & - & São Paulo State. & Acceptable & $\begin{array}{c}\text { Franceschini et al. } \\
(2013)\end{array}$ \\
\hline & 100 & $\begin{array}{l}316.31 \\
2,742.3\end{array}$ & $\begin{array}{c}16.3 \\
2,742.3\end{array}$ & $\begin{array}{c}24-1,113 \\
1,979-4,269\end{array}$ & & $\begin{array}{c}\text { Mato Grosso do } \\
\text { Sul State }\end{array}$ & $\begin{array}{c}\text { Acceptabl } \\
\text { Unacceptable }\end{array}$ & $\begin{array}{l}\text { Jerônimo et al. } \\
\text { (2014) }\end{array}$ \\
\hline & 97 & 11.3 & 11.5 & $1-58$ & 439 & ParanáState. & Acceptable & Present study \\
\hline \multirow{3}{*}{ 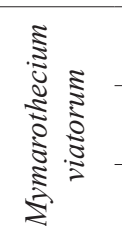 } & 100 & 277 & 277 & $54-854$ & 1,662 & Ceará State. & - & $\begin{array}{l}\text { Cohen and Kohn } \\
\text { (2009) }\end{array}$ \\
\hline & 72.7 & 27.5 & 19.9 & - & - & São Paulo State & Acceptable & $\begin{array}{c}\text { Franceschini et al. } \\
(2013)\end{array}$ \\
\hline & 95 & 27.1 & 25.7 & $2-188$ & 1,030 & Paraná State. & - & Present study \\
\hline
\end{tabular}


Table 6. Prevalence (P), Mean intensity (MI), Mean abundance (MA) and Total number of Anacanthorus penilabiatus and Mymarothecium viatorum from different parental host species.

\begin{tabular}{lccccc}
\hline \multirow{2}{*}{ Host } & \multicolumn{5}{c}{ Anacanthorus penilabiatus } \\
\cline { 2 - 6 } & $\mathbf{P}(\%)$ & MI & MA & $\begin{array}{c}\text { Total } \\
\text { number }\end{array}$ & Reference \\
\hline Piaractus mesopotamicus & 50 & 23.6 & 11.8 & 74 & Cohen and Kohn (2009) \\
\hline Piaractus brachypomus & 83.3 & 17.5 & 15 & 112 & Cohen and Kohn (2009) \\
\hline $\begin{array}{l}\text { (Piaractus mesopotamicus } \mathbf{x} \\
\text { Colossoma macropomum) }\end{array}$ & 11.7 & 433.8 & Tavares-Dias et al. (2008) \\
\hline $\begin{array}{l}\text { (Piaractus mesopotamicus } \mathbf{x} \\
\text { Piaractus brachypomus) }\end{array}$ & 77 & 7.5 & 5.8 & Franceschini et al. (2013) \\
\hline $\begin{array}{l}\text { Piaractus mesopotamicus } \\
\text { Piaractus brachypomus }\end{array}$ & 100 & \multicolumn{7}{c}{ Mymarothecium viatorum } & & \\
\hline $\begin{array}{l}\text { (Piaractus mesopotamicus } \mathbf{x} \\
\text { Piaractus brachypomus) }\end{array}$ & 85 & 105.7 & 105.7 & 740 & Cohen and Kohn (2009) \\
\hline
\end{tabular}

\section{Conclusions}

This study showed high prevalence results in all the species, although the features of the cages were according recommended range when rearing tropical species. A. toledoensis, was the species with higher rates of prevalence, mean intensity and mean abundance. The other three species have high rates of prevalence, but low values of mean intensity and mean abundance. The Monogenoidea collected in P. mesopotamicus showed the typical aggregated distribution pattern, and the abundance and the prevalence did not shown any correlation with the total length of hosts.

\section{Acknowledgements}

We are grateful to the Itaipú Binational Hydroelectric Power Station for letting us examine the fish in their facilities and to the Coordination Office for Improvement of Universitylevel Personnel (Coordenação de Aperfeiçoamento de Pessoal de Nivel Superior) for a doctoral fellowship.

\section{References}

ALEXANDRINO, A.C., RANZANI-PAIVA, M.J.T., ESHIKAWA, C.M., ARANA, S., MANDELLI JÚNIOR, J. and EIRAS, A.C., 1995. Infestação aguda por Henneguya sp. (Protozoa, Myxosporea) e Dactylogyridae (Platyhelminthes, Monogenea), em Pacu, Piaractus mesopotamicus (Holmberg, 1887) (Osteichthyes, Characidae). Boletim do Instituto de Pesca, vol. 22, pp. 115-119.

BAGGE, A.M., POULIN, R. and VALTONEN, E.T., 2004. Fish population size, and not density, as the determining factor of parasite infection: a case study. Parasitology, vol. 128, no. pt 3, pp. 305-313. PMid:15074879. http://dx.doi.org/10.1017/ S0031182003004566.

BELO, M.A., FENERICK JUNIOR, J., SOARES, V.E. and MORAES, F.R., 2005. Suplementação com DL-a acetato de tocoferila e parasitismo por Anacanthorus penilabiatus (Monogenea:
Dactylogyridae) em Piaractus mesopotamicus (Osteichthyes: Characidae). Acta Scientiarum, vol. 27, pp. 73-79.

BOEGER, W.A., HUSAK, W.S. and MARTINS, M.L., 1995. Neotropical Monogenoidea. 25. Anacanthorus penilabiatus n.sp. (Dactylogyridae: Ancyrocephalinae) from Piaractus mesopotamicus (Osteichthyes: Serrasalmidae), cultivated in the State of São Paulo, Brazil. Memorias do Instituto Oswaldo Cruz, vol. 90, no. 6, pp. 699-701. http://dx.doi.org/10.1590/S0074-02761995000600008.

BUSH, A.O., LAFFERTY, K.D., LOTZ, J.M. and SHOSTAK, A.W., 1997. Parasitology meets ecology on its own terms: Margolis et al. revisited. The Journal of Parasitology, vol. 83, no. 4, pp. 575-583. PMid:9267395. http://dx.doi.org/10.2307/3284227.

CAMPOS, C.M., MORAES, J.R.E. and MORAES, F.R., 2011. Histopathology of gills of Piaractus mesopotamicus (Holmberg, 1887) and Prochilodus lineatus (Valenciennes, 1836) infested by monogenean and myxosporea, caugth in Aquidauana River, State of Mato Grosso do Sul, Brazil. Revista Brasileira de Parasitologia Veterinária, vol. 20, no. 1, pp. 67-70. PMid:21439236. http:// dx.doi.org/10.1590/S1984-29612011000100014.

CARRASCHI, S.P., BARBUIO, R., IKEFUTI, C.V., FLORÊNCIO, T., CRUZ, C. and RANZANI-PAIVA, M.J.T., 2014. Effectiveness of therapeutic agents in disease treatment in Piaractus mesopotamicus. Aquaculture (Amsterdam, Netherlands), vol. 431, pp. 124-128. http://dx.doi.org/10.1016/j.aquaculture.2013.12.026.

COHEN, S.C. and KOHN, A., 2005. Anew species of Mymarothecium and new hosts and geographical records for M. viatorum (Monogenea: Dactylogyridae) parasites of freshwater fishes in Brazil. Folia Parasitologica, vol. 52, no. 4, pp. 307-310. PMid:16405294. http://dx.doi.org/10.14411/fp.2005.042.

COHEN, S.C. and KOHN, A., 2008. South American Monogenea: list of species, hosts and geographical distribution from 1997 to 2008. Zootaxa, vol. 1924, pp. 1-42.

COHEN, S.C. and KOHN, A., 2009. On Dactylogyridae (Monogenea) of four species of characid fishes from Brazil. Check List, vol. 5, no. 2, pp. 351-356. http://dx.doi.org/10.15560/5.2.351.

CRUZ, C., MACHADO NETO, J.G., FUJIMOTO, R.Y., HENARES, M.N.P. and DUÓ, D.A., 2008. Eficácia do paration metílico e do extrato aquoso de folhas secas de nim no controle de 
Anacanthorus penilabiatus (Monogenoidea) em pacu (Piaractus mesopotamicus). Boletim do Instituto de Pesca, vol. 34, pp. 61-69.

EIRAS, J.C., RANZANI-PAIVA, M.J.T., ISHIKAWA, C.M. and ALEXANDRINO, A.C., 1995. Ectoparasites of semi-intensively farmed tropical freshwater fish Piaractus mesopotamicus, Prochilodus lineatus and Colossoma macropomum in Brazil. Bulletin of the European Association of Fish Pathologists, vol. 15, pp. 148-151.

FANNES, W., MAARTEN, P.M., VANHOVE, M.P.M., HUYSE, T. and PALADINI, G., 2015. A scanning electron microscope technique for studying the sclerites of Cichlidogyrus. Parasitology Research, vol. 114, no. 5, pp. 2031-2034. PMid:25828814. http:// dx.doi.org/10.1007/s00436-015-4446-7.

FIGUEIREDO, A.B., 2011. Influência de banho de imersão com babosa, Aloe barbadensis (Miller, 1768) sobre os parâmetros hematológicos e Monogenoidea parasites de pacu, Piaractus mesopotamicus (Holmberg, 1887). Florianópolis: Universidade Federal de Santa Catarina, 22 p. Trabalho de Conclusão de Curso de Engenharia de Aquicultura.

FRANCESCHINI, L., ZAGO, A.C., SCHALCH, S.H.C., GARCIA, F., ROMERA, D.M. and SILVA, R., 2013. Parasitic infections of Piaractus mesopotamicus and hybrid (P. mesopotamicus $\mathrm{x}$ Piaractus brachypomus) cultured in Brazil. Revista Brasileira de Parasitologia Veterinária, vol. 22, no. 3, pp. 407-414. PMid:24142174. http:// dx.doi.org/10.1590/S1984-29612013000300015.

FUJIMOTO, R.Y., CASTRO, M.P., MARTINS, M.L., MORAES, F.R., VARELLA, J.E.A. and DINIZ, D.G., 2010. Effects of Chromium Supplementation on the infrapopulations of Anacanthorus penilabiatus (Monogenoidea) and Piscinoodinium pillulare (Dinoflagellida) parasites of Piaractus mesopotamicus (Characidae). Brazilian Archives of Biology and Technology, vol. 53, no. 4, pp. 827-833. http://dx.doi.org/10.1590/S151689132010000400011

GOMES, L.C., CHIPPARI-GOMES, A.R., LOPES, N.P., ROUBACH, R. and ARAUJO-LIMA, C., 2001. Efficacy of benzocaine as an anesthetic in juvenile tambaqui Colossoma macropomum. Journal of the World Aquaculture Society, vol. 32, no. 4, pp. 426-431. http://dx.doi.org/10.1111/j.1749-7345.2001.tb00470.x.

HUMASON, G.L., 1979. Animal tissue techniques. San Francisco: W.H. Freeman and Company.

JÉGU, M., 2003. Serrasalminae (Pacus and piranhas). In: R.E. REIS, SOK and C.J. FERRARIS JUNIOR, eds. Checklist of the freshwater fishes of South and Central America. Porto Alegre: EDIPUCRS, pp. 182-196.

JERÔNIMO, G.T., PÁDUA, S.B., BAMPI, D., GONÇALVES, E.L.T., GARCIA, P., ISHIKAWA, M.M. and MARTINS, M.L., 2014. Haematological and histhological analysis in South American fish Piaractus mesopotamicus parasitized by monogenean (Dactylogyridae). Brazilian Journal of Biology = Revista Brasileira de Biologia, vol. 74, no. 4, pp. 1000-1006. PMid:25627614. http://dx.doi.org/10.1590/1519-6984.09513.

KOHN, A. and COHEN, S.C., 1998. South American Monogenea: list of species, hosts and geographical distribution. International Journal for Parasitology, vol. 28, no. 10, pp. 1517-1554. PMid:9801914. http://dx.doi.org/10.1016/S0020-7519(98)00083-6.

KRITSKY, D.C., LEIBY, P.D. and KAYTON, R.J., 1978. A rapid stain technique for haptoral bars of Gyrodactylus species (Monogenea). The Journal of Parasitology, vol. 69, no. 1, pp. 862-865. PMid:76672.
LEÃO, M.S.L., SÃO CLEMENTE, S.C. and COHEN, S.C., 2015. Anacanthorus toledoensis $\mathrm{n}$. sp. and Mymarothecium ianwhittingtoni n. sp. (Dactylogyridae: Monogenoidea) parasitizing cage-reared Piaractus mesopotamicus (Characiformes, Characidae) in the State of Paraná, Brazil. Comparative Parasitology, vol. 82, no. 2, pp. 268-273. http://dx.doi.org/10.1654/4759.1.

LIZAMA, M.A.P., TAKEMOTO, R.M., RANZANI-PAIVA, M.J.T., AYROSA, L.M.S. and PAVANELLI, G.C., 2007. Relação parasito-hospedeiro em peixes de piscicultura da região de Assis, estado de São Paulo, Brasil. 2. Piaractus mesopotamicus (Holmberg, 1887). Acta Scientiarum Biological Sciences, vol. 29, pp. 437-445. http://dx.doi.org/10.4025/actascibiolsci.v29i2.594.

LUDWING, J.A. and REYNOLDS, J.F., 1988. Statistical Ecology: a primer methods and Computing. Wiley-Interscience Publications.

LUQUE, J.L., 2004. Parasitologia de peixes marinhos na América do Sul: estado atual e perspectivas. In: M.J.T. RANZANI-PAIVA, R.M. TAKEMOTO and M.A.P. LIZAMA. Sanidade de organismos aquáticos. São Paulo: Varela, pp. 199-215.

LUQUE, J.L., ALVES, D.R. and RIBEIRO, R.S., 2003. Community ecology of the metazoan parasites of Banded Croaker, Paralonchurus brasiliensis (Osteichthyes: Sciaenidae), from the coastal zone of the State of Rio de Janeiro, Brazil. Acta Scientiarum Biological Sciences, vol. 25, pp. 273-278. http://dx.doi.org/10.4025/ actascibiolsci.v25i2.2009.

MARCOGLIESE, D.J., 2001. Pursuing parasites up the food chain: implications of food web structure and function on parasite communities in aquatic systems. Acta Parasitologica, vol. 46, pp. 82-93.

MARTINS, M.L. and ROMERO, N.G., 1996. Efectos del parasitismo sobre el tejido branquial em peces cultivados: Estudio parasitologico e histopatologico. Revista Brasileira de Zoologia, vol. 13, no. 2, pp. 489-500. http://dx.doi.org/10.1590/ S0101-81751996000200017.

MARTINS, M.L., CASTAGNDLI, N., ZUIM, S.M.F. and URBINATI, E.C., 1995. Influência de diferentes níveis de vitamina C na ração sobre parâmetros hematológicos de alevinos de Piaractus mesopotamicus Hoemberg (Osteichthyes, Characidae). Revista Brasileira de Zoologia, vol. 12, no. 3, pp. 609-618. http://dx.doi. org/10.1590/S0101-81751995000300016.

MARTINS, M.L., 1998. Evaluation of the addition of ascorbic acid to the ration of cultivade Piaractus mesopotamicus (Characidae) on the infrapopulation of Anacanthorus penilabiatus (Monogenea). Brazilian Journal of Medical and Biological Research, vol. 31, no. 5, pp. 655-658. PMid:9698770. http://dx.doi.org/10.1590/ S0100-879X1998000500008

MARTINS, M.L., MORAES, F.R., FUJIMOTO, R.Y., ONAKA, E.M., NOMURA, D.T., SILVA, C.A.H. and SCHALCH, S.H.C., 2000. Parasitic infections in cultivated freshwater fishes a survey of diagnosticated cases from 1993 to 1998. Revista Brasileira de Parasitologia Veterinária, vol. 9, pp. 23-28.

MARTINS, M.L., ONAKA, E.M., MORAES, F.R., BOZZO, F.R., PAIVA, A.M.F.C. and GONÇALVES, A., 2002a. Recent studies on parasitic infections of freshwater cultivated fish in the state of São Paulo, Brazil. Acta Scientiarum, vol. 24, pp. 981-985.

MARTINS, M.L., MORAES, F.R., MIYAZAKI, D.M.Y., BRUM, C.D., ONAKA, E.M., FENERICK JUNIOR, J. and BOZZO, F.R., 2002b. Alternative treatment for Anacanthorus penilabiatus (Monogenea: Dactylogyridae) infection in cultivated pacu, Piaractus mesopotamicus (Osteichthyes: Characidae) in Brazil and its haematological effects. Parasite (Paris, France), vol. 9, 
no. 2, pp. 175-180. PMid:12116864. http://dx.doi.org/10.1051/ parasite/2002092175.

ONAKA, E.M., MARTINS, M.L. and MORAES, F.R., 2003. Eficácia do albendazol e praziquantel no controle de Anacanthorus penilabiatus (monogenea: dactylogyridae), parasito de pacu Piaractus mesopotamicus (osteichthyes: characidae). I. Banhos terapêuticos. Boletim do Instituto de Pesca, vol. 29, pp. 101-107.

OSTRENSKY, A. and BOEGER, W., 1998. Piscicultura: fundamentos e técnicas de manejo. Guaíba: Agropecuária Ltda.

PAMPLONA-BASILIO, M.C., KOHN, A. and FEITOSA, V.A., 2001. New host records and description of the egg of Anacanthorus penilabiatus (Monogenea, Dactylogyridae). Memorias do Instituto Oswaldo Cruz, vol. 96, no. 5, pp. 667-668. PMid:11500767. http:// dx.doi.org/10.1590/S0074-02762001000500014.

PAVANELLI, G.C., EIRAS, J.C. and TAKEMOTO, R.M., 2008. Doenças de peixes: profilaxia, diagnóstico e tratamento. Maringá: EDUEM.

POULIN, R., 2000. Variation in the intraspecific relationship between fish length and intensity of parasitic infection: biological and statistical causes. Journal of Fish Biology, vol. 56, no. 1, pp. 123-137. http://dx.doi.org/10.1111/j.1095-8649.2000.tb02090.x.

POULIN, R., 2006. Variation in infection parameters among populations within parasite species: intrinsic properties versus local factors. International Journal for Parasitology, vol. 36, no. 8, pp. 877-885. PMid:16620823. http://dx.doi.org/10.1016/j. ijpara.2006.02.021.

POULIN, R., 2013. Explaining variability in parasite aggregation levels among host samples. Parasitology, vol. 140, no. 4, pp. 541-546. PMid:23343821. http://dx.doi.org/10.1017/S0031182012002053.

RUBIO-GODOY, M., 2007. Fish host-monogenean parasite interactions, with special reference to Polyopisthocotylea. In: L.I. TERRAZAS. Advances in the immunology of parasitic deseases. Kerala: Signpost, pp. 91-109.

SCHALCH, S.H.C., MORAES, J.R.E. and MORAES, F.R., 2006. Fauna parasitária de peixes oriundos de "pesque-pague" do município de Guariba, São Paulo, Brazil. Acta Scientiarum Biological Sciences, vol. 28, pp. 291-297.

SOUZA, M.L.R., MARTINS, L.M. and SANTOS, J.M., 2000. Microscopia eletrônica de varredura de parasitos branquiais de Piaractus mesopotamicus Holmberg, 1887 cultivados no Estado de São Paulo, Brasil. Acta Scientiarum Biological Sciences, vol. 22, pp. 527-531.
TAKEMOTO, R.M., PAVANELLI, G.C., LIZAMA, M.A.P., LUQUE, J.L. and POULIN, R., 2005. Host density as a major determinat of endoparasite species richness in fishes of floodplain of the upper Parana River, Brazil. Journal of Helminthology, vol. 79, pp. 75-84. PMid:15831117. http://dx.doi.org/10.1079/ JOH2004264.

TAVARES-DIAS, M., MARTINS, M.L., MORAES, F.R. and KRONKA, S.N., 2000. Fator de condição e relação esplenossomática em teleósteos de água doce naturalmente parasitados. Acta Scientiarum, vol. 22, pp. 533-537.

TAVARES-DIAS, M., MARTINS, M.L., SCHALCH, S.H.C., ONAKA, E.D., QUINTANA, C.I.F., MORAES, J.R.E. and MORAES, F.R., 2002. Alterações hematológicas e histopatológicas em pacu, Piaractus mesopotamicus Holmberg, 1887 (Osteichthyes, Characidae), tratado com sulfato de cobre (CuSO4). Acta Scientiarum, vol. 24, pp. 547-554.

TAVARES-DIAS, M., MORAES, F.R. and MARTINS, M.L., 2008. Hematological assessment in four Brazilian teleost fish with parasitic infections collected in feefishing from Franca, São Paulo, Brazil. Boletim do Instituto de Pesca, vol. 34, pp. 189-196.

TAVERNARI, F.C., BELLAY, S., TAKEMOTO, R.M., GUIDELLI, G.M., LIZAMA, M.A.P. and PAVANELLI, G.C., 2005. Ecological aspects of Diplectanum piscinarius (Platyhelminthes, Monogenea) parasite of gills of Plagioscion squamosissimus (Osteichthyes, Sciaenidae) in the Upper Paraná River floodplain, Brazil. Acta Scientiarum, vol. 27, pp. 225-229.

THATCHER, V.E. and BRITES-NETO, J., 1994. Diagnóstico, prevenção e tratamento das enfermidades de peixes neotropicais de água doce. Revista Brasileira de Medicina Veterinária, vol. 16, pp. 111-128.

URBINATI, E.C., GONÇALVES, F.D. and TAKAHASHI, L.S., 2010. Pacu (Piaractus mesopotamicus). In: B. BALDISSEROTTO and L.C. GOMES. Espécies nativas para piscicultura no Brasil. Santa Maria: UFSM, pp. 205-244.

VÁSQUES, N.Z.D., 2014. Índices parasitários en larvas, post larvas $y$ alevinos de Piaractus brachypomus "Paco" en relación a los factores ambientales, en el centro de investigaciones Quistococha del Instituto de investigaciones de la Amazonia Peruana. Iquitos: Universidad Nacional de la Amazonía Peruana. 79 p.

ZAR, J.H., 1996. Biostatistical analysis. 3rd ed. Upper Saddle River: Prentice-Hall. 